\title{
2- and 8-alkynyl-9-ethyladenines: Synthesis and biological activity at human and rat adenosine receptors
}

\author{
Rosaria Volpini ${ }^{1}$, Stefano Costanzi $^{1}$, Catia Lambertucci ${ }^{1}$, Sauro Vittori ${ }^{1}$, Claudia Martini ${ }^{2}$, \\ M. Letizia Trincavelli ${ }^{3}$, Karl-Norbert Klotz ${ }^{3}$ \& Gloria Cristalli ${ }^{1}$ \\ ${ }^{1}$ Dipartimento di Scienze Chimiche, Università di Camerino, Camerino, Italy; ${ }^{2}$ Dipartimento di Psichiatria, \\ Neurobiologia, Farmacologia e Biotecnologie, Università di Pisa, Pisa, Italy; ${ }^{3}$ Institut für Pharmakologie und \\ Toxikologie, Universität Würzburg, Würzburg, Germany
}

Received 2 September 2004; accepted in revised form 21 October 2004

Key words: adenosine, adenosine antagonists, adenosine receptors, antagonist, purine derivatives, substituted adenines

\begin{abstract}
The synthesis of a series of 9-ethyladenine derivatives bearing alkynyl chains in 2- or 8-position was undertaken, based on the observation that replacement of the sugar moiety in adenosine derivatives with alkyl groups led to adenosine receptor antagonists. All the synthesized compounds were tested for their affinity at human and $\operatorname{rat} \mathrm{A}_{1}, \mathrm{~A}_{2 \mathrm{~A}}$, and $\mathrm{A}_{3}$ adenosine receptors in binding assays; the activity at the human $\mathrm{A}_{2 \mathrm{~B}}$ receptor was determined in adenylyl cyclase experiments. Biological data showed that the 2-alkynyl derivatives possess good affinity and are slightly selective for the human $\mathrm{A}_{2 \mathrm{~A}}$ receptor. The same compounds tested on the rat $A_{1}$ and $A_{2 A}$ subtypes showed in general lower affinity for both receptors. On the other hand, the affinity of the 8-alkynyl derivatives at the human $\mathrm{A}_{1}, \mathrm{~A}_{2 \mathrm{~A}}$, and $\mathrm{A}_{2 \mathrm{~B}}$ receptors proved to be lower than that of the corresponding 2-alkynyl derivatives. On the contrary, the affinity of the same compounds for the human $\mathrm{A}_{3}$ receptor was improved, resulting in $\mathrm{A}_{3}$ selectivity. As in the case of the 2-alkynyl-substituted compounds, the 8alkynyl derivatives showed decreased affinity for rat receptors. However, it is worthwhile to note that the 8phenylethynyl-9-ethyladenine was the most active compound of the two series $\left(K_{\mathrm{i}}\right.$ in the nanomolar range) at both thehuman and rat $\mathrm{A}_{3}$ subtype. Docking experiments of the 2- and 8-phenylethynyl-9-ethyladenines, at a rhodopsin-based homology model, gave a rational explanation of the preference of the human $\mathrm{A}_{3}$ receptor for the 8-substituted compound.
\end{abstract}

\section{Introduction}

Adenosine is an autacoid involved in the regulation of many aspects of cellular metabolism [1] and mediates its effects through the activation of at least four human receptors (P1), belonging to the superfamily of G proteincoupled receptors, which have been recently cloned [2] and classified as $A_{1}, A_{2 A}, A_{2 B}$, and $A_{3}$ [3]. All subtypes have been cloned from a variety of species including the rat and human. Species differences for the $\mathrm{A}_{3}$ adenosine receptor (AdoR) are larger than for other AR subtypes, particularly between rodent and human receptors (only 74\% sequence identity between rat and human $\mathrm{A}_{3}$ amino acid sequence) [4]. This results in different affinities of ligands particularly antagonists - for rat versus human $\mathrm{A}_{3}$ receptors $[5,6]$. During the past decades many efforts have been directed toward the discovery of potent and selective adenosine receptor ligands aimed at finding novel drugs [7].

Most adenosine agonists possess a structure very close to that of the natural ligand adenosine; in contrast a wide range of structural classes have been characterized as

Correspondence to: Prof. Gloria Cristalli, Dipartimento di Scienze Chimiche, Università di Camerino, 62032 Camerino, Italy. Tel: +390737-402252; Fax: +39-0737-402295; E-mail: gloria.cristalli@unicam.it adenosine receptor antagonists and developed as potential therapeutic agents for CNS disorders, inflammatory diseases, asthma, kidney failure and ischaemic injuries [8].

However, only a few xanthine antagonists as caffeine and theophylline have been approved as drugs for their CNS stimulating, diuretic, and bronchodilating effects, respectively $[8,9]$.

In many papers it has been demonstrated that introduction of alkynyl chains in the 2-position of adenosine derivatives led to compounds endowed with high affinity at all adenosine receptors (AdoRs) [10-15], whereas the introduction of the same alkynyl chains in the 8-position resulted in 8-alkynyladenosines, which were unable to stimulate $\left[{ }^{35} \mathrm{~S}\right] \mathrm{GTP} \gamma \mathrm{S}$ binding, and inhibited that stimulated by NECA, yielded $\mathrm{A}_{3}$ antagonists [16, 17].

Moreover, we have published the synthesis and activities for the human AdoR subtypes of a series of 9-ethyladenines, substituted at the 2-, 6- and 8-positions, which behaved as AdoR antagonists [18-20]. In fact, replacement of the sugar moiety of adenosine with a methyl group led to a rather unselective antagonist of AdoR and adenine itself is a weak adenosine antagonist [21].

Recently, substituted adenine derivatives, prepared as hypoglycemic agents, were found to possess high potency at the $A_{2 B}$ AdoR subtype [22], whereas novel substituted 
$N^{6}$-cyclopentyladenine derivatives were characterized as neutral antagonists endowed with high affinity for the $\mathrm{A}_{1}$ AdoR [23].

Hence, starting from these observations and in order to widen our study on 9-ethyladenine derivatives, a series of 9-ethyladenines bearing alkynyl chains at the 2- or 8position were synthesized and tested at human and rat AdoR subtypes.

\section{Materials and methods}

\section{Chemistry}

Synthesis of the 2- and 8-alkynyl-9-ethylpurines 2-10, $12-19$, and 22

The synthesis of the 2-alkynyl-9-ethyladenines 2-10 and 8alkynyl-9-ethyladenines 12-19, was carried out starting from 2-iodo-9-ethyladenine (1; [18] or 8-bromo-9-ethyladenine (11; [18]), respectively, and are reported in Schemes 1 and 2. In order to obtain the final products compound $\mathbf{1}$ or $\mathbf{1 1}$ was reacted with the suitable terminal alkynes using a modification of the palladium catalyzed cross-coupling reaction [18].

However, for the synthesis of the 8-alkynyl derivative 22, 8-iodo-9-ethyladenine (21), obtained through the iodination of the 9-ethyladenine (20) [18] with iodine and lithiumdiisopropylamide (LDA), was used as the starting material.

This choice was due to the fact that reaction of 8-bromo9-ethyladenine (11) with $(R, S)$-phenylhydroxypropyne failed to give the corresponding 8-phenylhydroxypropynyl analogue, while the reaction was successful when the 8 -iodo analogue was used as starting material.

The synthesis of the derivatives $\mathbf{3}, \mathbf{9}, \mathbf{1 3}$, and $\mathbf{1 9}$ has been already published [18].

General synthetic procedures

Melting points were determined with a Büchi apparatus and areuncorrected. ${ }^{1} \mathrm{H}$ NMR spectra were obtained with Varian Gemini $200 \mathrm{MHz}$ or a Varian VXR 300-MHz spectrome-<smiles>CCn1cnc2c(N)nc(I)nc21</smiles>

1

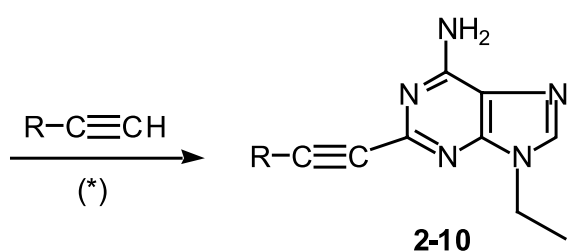

2-10
2; $\mathrm{R}=-\left(\mathrm{CH}_{2}\right)_{2}-\mathrm{CH}_{3}$

3; $\mathrm{R}=-\left(\mathrm{CH}_{2}\right)_{3}-\mathrm{CH}_{3}$

4; $\mathrm{R}=-\left(\mathrm{CH}_{2}\right)_{4}-\mathrm{OH}$

5; $\mathrm{R}=$-cyclohexyl

6; $R=1$-cyclohexenyl
7; $\mathrm{R}=-\mathrm{C}_{6} \mathrm{H}_{5}$

8; $\mathrm{R}=-\mathrm{C}_{6} \mathrm{H}_{4}-p-\mathrm{COCH}_{3}$

9; $\mathrm{R}=-\left(\mathrm{CH}_{2}\right)_{2}-\mathrm{C}_{6} \mathrm{H}_{5}$

10; $\mathrm{R}=(R, S)-\mathrm{CH}(\mathrm{OH})-\mathrm{C}_{6} \mathrm{H}_{5}$
( $\left.{ }^{*}\right) \mathrm{Cul},\left[\left(\mathrm{C}_{6} \mathrm{H}_{5}\right)_{3} \mathrm{P}_{2} \mathrm{PdCl}_{2}, \mathrm{Et}_{3} \mathrm{~N}\right.$ ter; $\delta$ in ppm, $J$ in $\mathrm{Hz}$. All exchangeable protons were confirmed by addition of $\mathrm{D}_{2} \mathrm{O}$. TLC were carried out on precoated TLC plates with silica gel 60 F-254 (Merck). For column chromatography, silica gel 60 (Merck) was used. Elemental analyses were determined on Carlo Erba model 1106 analyser and are within $\pm 0.4 \%$ of theoretical values.

General method for the synthesis of the 2- or 8-(ar)alkynyl9-ethyladenines $2,4-8,10,12,14-18$ and 22

To a solution of 1,11 or $21(0.84 \mathrm{mmol})$ in dry DMF and $\mathrm{CH}_{3} \mathrm{CN}$ [15 $\left.\mathrm{ml}(1: 2)\right]$, bis(triphenylphosphine)palladium dichloride $(12 \mathrm{mg}, 0.017 \mathrm{mmol})$ and $\mathrm{CuI}(0.84 \mathrm{mg}, 0.004$ $\mathrm{mmol}), \mathrm{Et}_{3} \mathrm{~N}(3.4 \mathrm{ml})$, and the appropriate terminal alkyne $(4.2 \mathrm{mmol})$ were added. The reaction mixture was stirred under an atmosphere of $\mathrm{N}_{2}$ at room temperature for the time reported for each compound. The solvent was removed in vacuo and the residue was chromatographed on a silica gel column or TLC plates eluting with a suitable mixture of solvents to give the desired derivatives $\mathbf{2 ,} \mathbf{4 - 8}$, 10, 12, 14-18 and 22.

9-Ethyl-2-pent-1-ynyl-9H-purin-6-ylamine (2). The reaction of 1 with 1-pentyne for $24 \mathrm{~h}$, followed by chromatography on a silica gel column eluting with $\mathrm{CHCl}_{3}-\mathrm{cC}_{6} \mathrm{H}_{12}-\mathrm{CH}_{3} \mathrm{OH}$ (88:10:2), gave $\mathbf{2}$ as a chromatographically pure amorphous solid. Yield 51\%, m.p. $105{ }^{\circ} \mathrm{C}$ (dec); ${ }^{1} \mathrm{H}$ NMR (DMSO- $d_{6}$ ) $\delta 0.97\left(\mathrm{t}, 3 \mathrm{H}, J=7.3 \mathrm{~Hz}, \mathrm{CH}_{2} \mathrm{CH}_{3}\right) ; 1.35(\mathrm{t}, 3 \mathrm{H}, J=7.0 \mathrm{~Hz}$, $\left.\mathrm{NCH}_{2} \mathrm{CH}_{3}\right) ; 1.54\left(\mathrm{~m}, 2 \mathrm{H}, \mathrm{CH}_{2} \mathrm{CH}_{3}\right) ; 2.35(\mathrm{t}, 2 \mathrm{H}, J=7.0 \mathrm{~Hz}$, $\left.\mathrm{C} \equiv \mathrm{CCH}_{2}\right) ; 4.11\left(\mathrm{q}, 2 \mathrm{H}, J=7.2 \mathrm{~Hz}, \mathrm{NCH}_{2}\right) ; 7.24(\mathrm{~s}, 2 \mathrm{H}$, $\mathrm{NH}_{2}$ ); 8.15 (s, $\left.1 \mathrm{H}, \mathrm{H}-8\right)$. Anal. Calcd. for $\mathrm{C}_{12} \mathrm{H}_{15} \mathrm{~N}_{5}$ (229.3): $\mathrm{C}, 62.86 ; \mathrm{H}, 6.59 ; \mathrm{N}, 30.54$. Found: $\mathrm{C}, 62.98 ; \mathrm{H}, 6.73$; $\mathrm{N}, 30.25$.

6-(6-Amino-9-ethyl-9H-purin-2-yl)-hex-5-yn-1-ol (4). The reaction of 1 with 5-hexynyl-1-ol for $48 \mathrm{~h}$, followed by chromatography on a silica gel column eluting with $\mathrm{CH}_{2} \mathrm{Cl}_{2}-\mathrm{cC}_{6} \mathrm{H}_{12}-\mathrm{CH}_{3} \mathrm{OH}$ (82:10:8), gave after crystallization from EtOH, 4, as white crystals. Yield 83\%, m.p. 138-140 ${ }^{\circ} \mathrm{C} \quad(\mathrm{dec}) ;{ }^{1} \mathrm{H}$ NMR (DMSO- $\left.d_{6}\right) \delta 1.35(\mathrm{t}, 3 \mathrm{H}$, $\left.J=7.0 \mathrm{~Hz}, \mathrm{CH}_{3}\right) ; 1.54\left(\mathrm{~m}, 4 \mathrm{H}, \mathrm{CH}_{2} \mathrm{CH}_{2}\right) ; 2.39(\mathrm{~m}, 2 \mathrm{H}$, $\left.\mathrm{C} \equiv \mathrm{CCH}_{2}\right) ; 3.41\left(\mathrm{~m}, 2 \mathrm{H}, \mathrm{CH}_{2} \mathrm{OH}\right) ; 4.11(\mathrm{q}, 2 \mathrm{H}, J=7.2 \mathrm{~Hz}$, $\left.\mathrm{NCH}_{2}\right) ; 4.42\left(\mathrm{t}, 1 \mathrm{H}, J=5.3 \mathrm{~Hz}, \mathrm{CH}_{2} \mathrm{OH}\right) ; 7.26\left(\mathrm{~s}, 2 \mathrm{H}, \mathrm{NH}_{2}\right)$; 8.16 (s, $1 \mathrm{H}, \mathrm{H}-8)$. Anal. Calcd. for $\mathrm{C}_{13} \mathrm{H}_{17} \mathrm{~N}_{5} \mathrm{O}$ (259.3): C, $60.21 ; \mathrm{H}, 6.61 ; \mathrm{N}, 27.01$. Found: C, 60.53; H, 6.79; N, 26.79.

2-Cyclohexylethynyl-9-ethyl-9H-purin-6-ylamine (5). The reaction of 1 with cyclohexylacetylene for $20 \mathrm{~h}$, followed by chromatography on a silica gel column eluting with $\mathrm{CHCl}_{3}-\mathrm{CH}_{3} \mathrm{OH}$ (99:1), gave, after crystallization from $\mathrm{EtOH}, \mathbf{5}$, as white crystals. Yield $62 \%$, m.p. $203-205^{\circ} \mathrm{C}$; ${ }^{1} \mathrm{H}$ NMR (DMSO- $\left.d_{6}\right) \delta 1.22-1.87\left(\mathrm{~m}, 8 \mathrm{H}, \mathrm{CH}_{3}\right.$ and $\mathrm{H}-$ cyclohexyl); 2.59 (m, 1H, C $\equiv \mathrm{CCH}) ; 4.12$ (q, 2H, $J=7.2$ $\left.\mathrm{Hz}, \mathrm{NCH}_{2}\right) ; 7.26\left(\mathrm{~s}, 2 \mathrm{H}, \mathrm{NH}_{2}\right) ; 8.16(\mathrm{~s}, 1 \mathrm{H}, \mathrm{H}-8)$. Anal. Calcd. for $\mathrm{C}_{15} \mathrm{H}_{19} \mathrm{~N}_{5}$ (269.3): C, 66.89; H, 7.11; N, 26.00 . Found: C, 67.13; H, 7.45; N, 25.77.

2-Cyclohex-1-enylethynyl-9-ethyl-9H-purin-6-ylamine (6). The reaction of $\mathbf{1}$ with 1-ethynylcyclohexene for $20 \mathrm{~h}$, followed by chromatography on a silica gel column eluting 


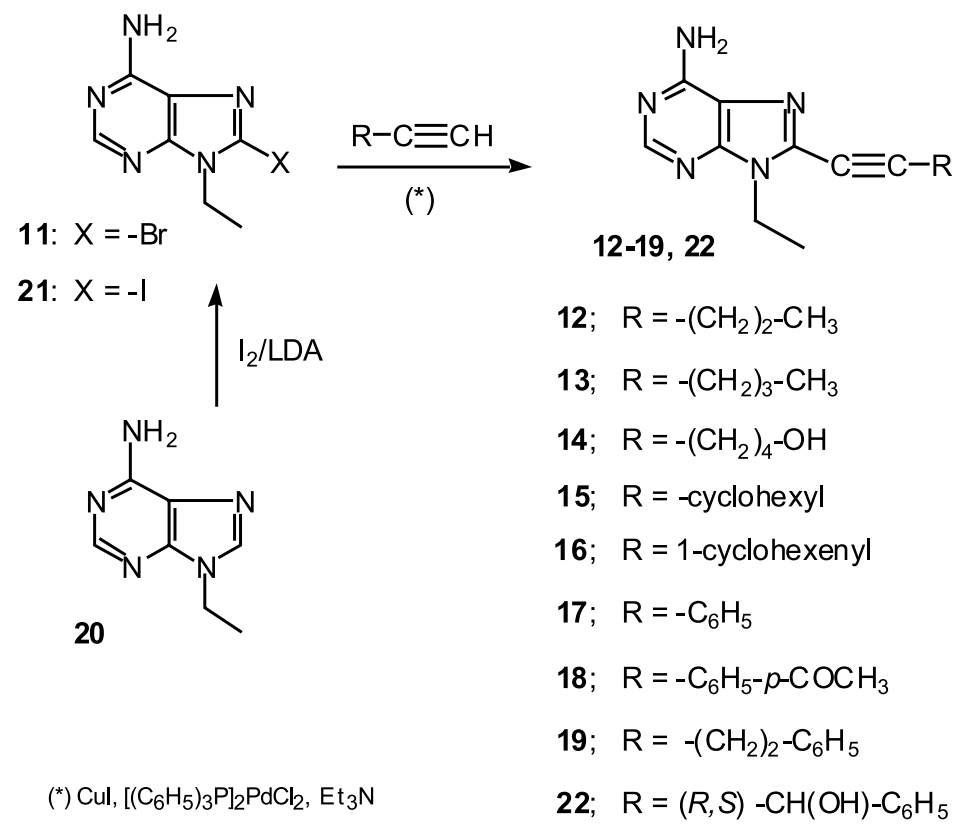

Scheme 2

with $\mathrm{CHCl}_{3}-\mathrm{CH}_{3} \mathrm{OH}$ (98:2), gave, after crystallization from $\mathrm{MeOH}, 6$, as white crystals. Yield $90 \%$, m.p. $>250{ }^{\circ} \mathrm{C} ;{ }^{1} \mathrm{H}$ NMR (DMSO- $\left.d_{6}\right) \delta 1.39\left(\mathrm{t}, 3 \mathrm{H}, J=7.2 \mathrm{~Hz}, \mathrm{CH}_{3}\right) ; 1.62(\mathrm{~m}$, 4H, H-cyclohexenyl); 2.15 (m, 4H, H-cyclohexenyl); 4.15 (q, 2H, $\left.J=7.5 \mathrm{~Hz}, \mathrm{NCH}_{2}\right) ; 6.30(\mathrm{~m}, 1 \mathrm{H}, \mathrm{CH}=\mathrm{C}) ; 7.35$ (bs, $\left.2 \mathrm{H}, \mathrm{NH}_{2}\right) ; 8.21(\mathrm{~s}, 1 \mathrm{H}, \mathrm{H}-8)$. Anal. Calcd. for $\mathrm{C}_{15} \mathrm{H}_{17} \mathrm{~N}_{5}$ (267.3): C, 67.39; H, 6.41; N, 26.20. Found: C, 67.68; H, $6.80 ; \mathrm{N}, 26.01$.

9-Ethyl-2-phenylethynyl-9H-purin-6-ylamine (7). The reaction of 1 with 1-phenylacetylene for $6 \mathrm{~h}$, followed by chromatography on a silica gel column eluting with $\mathrm{CH}_{2} \mathrm{Cl}_{2}-\mathrm{CH}_{3} \mathrm{OH}$ (99.5:0.5), gave, after crystallization from $\mathrm{EtOH}, 7$, as white crystals. Yield $85 \%$, m.p. $250{ }^{\circ} \mathrm{C}$ (dec); ${ }^{1} \mathrm{H}$ NMR (DMSO-d $d_{6} \delta 1.38\left(\mathrm{t}, 3 \mathrm{H}, J=7.5 \mathrm{~Hz}, \mathrm{CH}_{3}\right) ; 4.16$ (q, $\left.2 \mathrm{H}, J=7.2 \mathrm{~Hz}, \mathrm{CH}_{2}\right) ; 7.43\left(\mathrm{~m}, 5 \mathrm{H}, \mathrm{H}-\mathrm{Ph}\right.$ and $\mathrm{NH}_{2}$ ); $7.58(\mathrm{~m}, 2 \mathrm{H}, \mathrm{H}-\mathrm{Ph}) ; 8.23$ (s, 1H, H-8). Anal. calcd. for $\mathrm{C}_{15} \mathrm{H}_{13} \mathrm{~N}_{5}$ (263.3): C, 68.42; H, 4.98; N, 26.60. Found: $\mathrm{C}$, 68.78; H, 5.27; N, 26.35 .

1-[4-(6-Amino-9-ethyl-9H-purin-2-ylethynyl)-phenyl]ethanone (8). The reaction of $\mathbf{1}$ with 1-(4-ethynylphenyl) ethanone for $6 \mathrm{~h}$, followed by chromatography on a silica gel column eluting with $\mathrm{CH}_{2} \mathrm{Cl}_{2}-\mathrm{cC}_{6} \mathrm{H}_{12}-\mathrm{CH}_{3} \mathrm{OH}$ (85:10:15), gave, after crystallization from $\mathrm{EtOH}, \mathbf{8}$, as white crystals. Yield $67 \%$, m.p. $>230{ }^{\circ} \mathrm{C} ;{ }^{1} \mathrm{H}$ NMR $\left(\mathrm{DMSO}-d_{6}\right) \delta 1.39\left(\mathrm{t}, 3 \mathrm{H}, J=7.3 \mathrm{~Hz}, \mathrm{CH}_{2} \mathrm{CH}_{3}\right) ; 2.59$ (s, $\left.3 \mathrm{H}, \mathrm{COCH}_{3}\right) ; 4.17$ (q, 2H, $\left.J=7.5 \mathrm{~Hz}, \mathrm{CH}_{2} \mathrm{CH}_{3}\right) ; 7.46$ (s, $\left.2 \mathrm{H}, \mathrm{NH}_{2}\right) ; 7.72(\mathrm{~d}, 2 \mathrm{H}, J=8.2 \mathrm{~Hz}, \mathrm{H}-\mathrm{Ph}) ; 7.98$ (d, 2H, $J=$ $8.2 \mathrm{~Hz}, \mathrm{H}-\mathrm{Ph}) ; 8.25$ (s, 1H, H-8). Anal. Calcd. for $\mathrm{C}_{17} \mathrm{H}_{15} \mathrm{~N}_{5} \mathrm{O}$ (305.3): C, 66.87; H, 4.95; N, 22.94. Found: C, 66.98; H, 5.24; N, 22.78 .

3-(6-Amino-9-ethyl-9H-purin-2-yl)-1-phenyl-prop-2-yn-1ol (10). The reaction of 1 with $(R, S)$-1-phenyl-2-propyn- 1-ol for $20 \mathrm{~h}$, followed by chromatography on a silica gel column eluting with $\mathrm{CHCl}_{3}-\mathrm{CH}_{3} \mathrm{OH}$ (96:4), gave, after crystallization from EtOH, 10, as white crystals. Yield $57 \%$, m.p. $>250{ }^{\circ} \mathrm{C} ;{ }^{1} \mathrm{H}$ NMR $\left(\mathrm{DMSO}-d_{6}\right) \delta 1.36(\mathrm{t}, 3 \mathrm{H}$, $\left.J=6.9 \mathrm{~Hz}, \mathrm{CH}_{3}\right) ; 4.13\left(\mathrm{q}, 2 \mathrm{H}, J=7.2 \mathrm{~Hz}, \mathrm{CH}_{2}\right) ; 5.58$ (d, $1 \mathrm{H}, J=6.0 \mathrm{~Hz}, \mathrm{CHOH}) ; 6.24(\mathrm{~d}, 1 \mathrm{H}, J=6.0 \mathrm{~Hz}, \mathrm{CHOH})$; $7.36\left(\mathrm{~m}, 5 \mathrm{H}, \mathrm{H}-\mathrm{Ph}\right.$ and $\left.\mathrm{NH}_{2}\right) ; 7.51(\mathrm{~d}, 2 \mathrm{H}, J=8.4 \mathrm{~Hz}, \mathrm{H}-$ $\mathrm{Ph}$ ); 8.19 (s, 1H, H-8). Anal. calcd. for $\mathrm{C}_{16} \mathrm{H}_{15} \mathrm{~N}_{5} \mathrm{O}$ (293.3): C, 65.52; H, 5.15; N, 23.88. Found: C, 65.90; H, 5.29; N, 23.61 .

9-Ethyl-8-pent-1-ynyl-9H-purin-6-ylamine (12). The reaction of 11 with 1-pentyne for $48 \mathrm{~h}$, followed by chromatography on a silica gel column eluting with $\mathrm{CHCl}_{3}-\mathrm{CH}_{3} \mathrm{OH}$ (98:2), gave, after crystallization from $\mathrm{MeOH}, 12$, as white crystals. Yield $73 \%$, m.p. 182-184 ${ }^{\circ} \mathrm{C} ;{ }^{1} \mathrm{H}$ NMR (DMSO- $\left.d_{6}\right) \delta 1.04(\mathrm{t}, 3 \mathrm{H}, J=7.2 \mathrm{~Hz}$, $\left.\mathrm{CH}_{2} \mathrm{CH}_{3}\right) ; 1.35$ (t, 3H, $\left.J=7.2 \mathrm{~Hz}, \mathrm{NCH}_{2} \mathrm{CH}_{3}\right) ; 1.64(\mathrm{~m}, 2 \mathrm{H}$, $\left.\mathrm{CH}_{2} \mathrm{CH}_{3}\right) ; 2.57$ (t, $\left.2 \mathrm{H}, \mathrm{J}=6.9 \mathrm{~Hz}, \mathrm{C} \equiv \mathrm{CCH}_{2}\right) ; 4.20(\mathrm{q}, 2 \mathrm{H}$, $\mathrm{J}=7.2 \mathrm{~Hz}, \mathrm{NCH}_{2}$ ); 7.37 (bs, 2H, $\mathrm{NH}_{2}$ ); 8.16 (s, 1H, H-2). Anal. Calcd. for $\mathrm{C}_{12} \mathrm{H}_{15} \mathrm{~N}_{5}$ (229.3): C, 62.86; H, 6.59; N, 30.54. Found: C, 63.14; H, 6.84; N, 30.27.

6-(6-Amino-9-ethyl-9H-purin-8-yl)-hex-5-yn-1-ol (14). The reaction of 11 with 5-hexynyl-1-ol for $48 \mathrm{~h}$, followed by chromatography on a silica gel column eluting with $\mathrm{CHCl}_{3}-\mathrm{CH}_{3} \mathrm{OH}$ (95:5), gave, after crystallization from $\mathrm{MeOH}, 14$, as white crystals. Yield 73\%, m.p. 162-164 ${ }^{\circ} \mathrm{C} ;{ }^{1} \mathrm{H}$ NMR (DMSO- $\left.d_{6}\right) \delta 1.35$ (t, 3H, $J=7.2$ $\left.\mathrm{Hz}, \mathrm{CH}_{3}\right) ; 1.63\left(\mathrm{~m}, 4 \mathrm{H}, \mathrm{CH}_{2} \mathrm{CH}_{2}\right) ; 2.60(\mathrm{t}, 2 \mathrm{H}, J=6.6 \mathrm{~Hz}$, $\left.\mathrm{C} \equiv \mathrm{CCH}_{2}\right) ; 3.46\left(\mathrm{~m}, 2 \mathrm{H}, \mathrm{CH}_{2} \mathrm{OH}\right) ; 4.20(\mathrm{q}, 2 \mathrm{H}, J=7.5 \mathrm{~Hz}$, $\left.\mathrm{NCH}_{2}\right) ; 4.48$ (t, $\left.1 \mathrm{H}, J=5.1 \mathrm{~Hz}, \mathrm{OH}\right) ; 7.36$ (bs, $2 \mathrm{H}, \mathrm{NH}_{2}$ ); 8.16 (s, 1H, H-2). Anal. Calcd. for $\mathrm{C}_{13} \mathrm{H}_{17} \mathrm{~N}_{5} \mathrm{O}$ (259.3): C, 60.21; H, 6.61; N, 27.01. Found: C, 60.49; H, 6.83; N, 26.76 . 
8-Cyclohexenylethynyl-9-ethyl-9H-purin-6-ylamine (15). The reaction of $\mathbf{1 1}$ with cyclohexylacetylene for $24 \mathrm{~h}$, followed by chromatography on a silica gel column eluting with $\mathrm{CHCl}_{3}-\mathrm{cC}_{6} \mathrm{H}_{12}-\mathrm{CH}_{3} \mathrm{OH}$ (55:40:5), gave after crystallization from $\mathrm{MeOH}, \mathbf{1 5}$, as white crystals. Yield $85 \%$, m.p. $247{ }^{\circ} \mathrm{C}(\mathrm{dec}) ;{ }^{1} \mathrm{H}$ NMR (DMSO- $\left.d_{6}\right) \delta 1.26-1.83$ (m, 13H, H-cyclohexyl and $\left.\mathrm{CH}_{3}\right) ; 2.79(\mathrm{~m}, 1 \mathrm{H}, \mathrm{CH}-\mathrm{C} \equiv \mathrm{C})$; 4.15 (q, 2H, $J=7.1 \mathrm{~Hz}, \mathrm{~N}-\mathrm{CH}_{2}$ ); 7.33 (bs, 2H, $\mathrm{NH}_{2}$ ); 8.11 (s, 1H, H-2). Anal. Calcd. for $\mathrm{C}_{15} \mathrm{H}_{19} \mathrm{~N}_{5}$ (269.3): C, 66.89; H, 7.11; N, 26.00. Found: C, 67.25; H, 7.41; N, 25.79.

8-Cyclohex-1-enylethynyl-9-ethyl-9H-purin-6-ylamine (16). The reaction of $\mathbf{1 1}$ with 1-ethynylcyclohexene for $36 \mathrm{~h}$, followed by chromatography on a silica gel column eluting with $\mathrm{CHCl}_{3}-\mathrm{CH}_{3} \mathrm{OH}$ (99:1), gave, after crystallization from $\mathrm{MeOH}, 16$, as white crystals. Yield 65\%, m.p. $160{ }^{\circ} \mathrm{C}(\mathrm{dec}) ;{ }^{1} \mathrm{H}$ NMR (DMSO-d 6$) \delta 1.36(\mathrm{t}, 3 \mathrm{H}, J=7.2$ $\left.\mathrm{Hz}, \mathrm{CH}_{3}\right) ; 1.64$ (m, 4H, H-cyclohexenyl); 2.21 (m, 4H, Hcyclohexenyl); 4.21 (q, 2H, $\left.J=7.2 \mathrm{~Hz}, \mathrm{NCH}_{2}\right) ; 6.47$ (m, $1 \mathrm{H}, \mathrm{CH}=\mathrm{C}) ; 7.43$ (bs, 2H, $\left.\mathrm{NH}_{2}\right) ; 8.18(\mathrm{~s}, 1 \mathrm{H}, \mathrm{H}-2)$. Anal. Calcd. for $\mathrm{C}_{15} \mathrm{H}_{17} \mathrm{~N}_{5}$ (267.3): C, 67.39; H, 6.41; N, 26.20. Found: C, 67.74; H, 6.56; N, 26.03.

9-Ethyl-8-phenylethynyl-9H-purin-6-ylamine (17). The reaction of 11 with 1-phenylacetylene for $72 \mathrm{~h}$, followed by chromatography on a silica gel column eluting with $\mathrm{CH}_{2} \mathrm{Cl}_{2}-\mathrm{cC}_{6} \mathrm{H}_{12}-\mathrm{CH}_{3} \mathrm{OH}$ (85:10:5), gave, after crystallization from $\mathrm{MeOH}, 17$, as white crystals. Yield 52\%, m.p. 249-251 ${ }^{\circ} \mathrm{C}$; ${ }^{1} \mathrm{H}$ NMR (DMSO- $\left.d_{6}\right) \delta 1.43$ (t, $3 \mathrm{H}, J=7.2$ $\left.\mathrm{Hz}, \mathrm{CH}_{3}\right) ; 4.33$ (q, 2H, $\left.J=7.3 \mathrm{~Hz}, \mathrm{NCH}_{2}\right) ; 7.53$ (m, 5H, H$\mathrm{Ph}$ and $\left.\mathrm{NH}_{2}\right) ; 7.72(\mathrm{~m}, 2 \mathrm{H}, \mathrm{H}-\mathrm{Ph}) ; 8.21(\mathrm{~s}, 1 \mathrm{H}, \mathrm{H}-2)$. Anal. Calcd. for $\mathrm{C}_{15} \mathrm{H}_{13} \mathrm{~N}_{5}$ (263.3): C, 68.42; H, 4.98; N, 26.60. Found: C, 68.77; H, 5.35; N, 26.43.

1-[4-(6-Amino-9-ethyl-9H-purin-8-ylethynyl)-phenyl]ethanone (18). The reaction of $\mathbf{1 1}$ with 1-(4-ethynylphenyl) ethanone for $16 \mathrm{~h}$, followed by chromatography on a silica gel column eluting with $\mathrm{CHCl}_{3}-\mathrm{CH}_{3} \mathrm{OH}$ (90:10), gave, after crystallization from $\mathrm{MeOH}, \mathbf{1 8}$, as white crystals. Yield 40\%, m.p. $>250{ }^{\circ} \mathrm{C} ;{ }^{1} \mathrm{H}$ NMR (DMSO$\left.d_{6}\right) \delta 1.42\left(\mathrm{t}, 3 \mathrm{H}, J=6.9 \mathrm{~Hz}, \mathrm{CH}_{2} \mathrm{CH}_{3}\right) ; 2.63(\mathrm{~s}, 3 \mathrm{H}$, $\left.\mathrm{COCH}_{3}\right) ; 4.34\left(\mathrm{q}, 2 \mathrm{H}, J=6.9 \mathrm{~Hz}, \mathrm{CH}_{2}\right) ; 7.52$ (bs, 2H, $\left.\mathrm{NH}_{2}\right) ; 7.85$ (d, 2H, $\left.J=8.4 \mathrm{~Hz}, \mathrm{H}-\mathrm{Ph}\right) ; 8.06(\mathrm{~d}, 2 \mathrm{H}, J=8.4$ $\mathrm{Hz}, \mathrm{H}-\mathrm{Ph}) ; 8.21(\mathrm{~s}, 1 \mathrm{H}, \mathrm{H}-2)$. Anal. Calcd. for $\mathrm{C}_{17} \mathrm{H}_{15} \mathrm{~N}_{5} \mathrm{O}$ (305.3): C, 66.87; H, 4.95; N, 22.94. Found: C, 67.23; H, $5.25 ; \mathrm{N}, 22.78$.

3-(6-Amino-9-ethyl-9H-purin-8-yl)-1-phenyl-prop-2-yn-1ol (22). The reaction of 21 with $(R, S)$-1-phenyl-2-propyn-1ol for $36 \mathrm{~h}$, followed by chromatography on a silica gel column eluting with $\mathrm{CHCl}_{3}-\mathrm{CH}_{3} \mathrm{OH}$ (96:4), gave, after crystallization from $\mathrm{CH}_{3} \mathrm{CN}-\mathrm{MeOH}, \mathbf{2 2}$, as white crystals. Yield $13 \%$, m.p. $226-228{ }^{\circ} \mathrm{C} ;{ }^{1} \mathrm{H}$ NMR (DMSO- $\left.d_{6}\right) \delta 1.33$ (t, $3 \mathrm{H}, J=7.2 \mathrm{~Hz}, \mathrm{CH}_{3}$ ); 4.21 (q, $2 \mathrm{H}, J=7.2 \mathrm{~Hz}, \mathrm{NCH}_{2}$ ); 5.77 (d, $1 \mathrm{H}, J=6.1 \mathrm{~Hz}, \mathrm{CHOH}) ; 6.49(\mathrm{~d}, 1 \mathrm{H}, J=6.1 \mathrm{~Hz}$, $\mathrm{CHOH}) ; 7.41$ (m, 5H, H-Ph and $\left.\mathrm{NH}_{2}\right) ; 7.59$ (m, 2H, H-Ph); 8.19 (s, 1H, H-2). Anal. Calcd. for $\mathrm{C}_{16} \mathrm{H}_{15} \mathrm{~N}_{5} \mathrm{O}$ (293.3): C, 65.52; H, 5.15; N, 23.88. Found: C, 65.81; H, 5.27; N, 23.50 .
9-Ethyl-8-iodo-9H-purin-6-ylamine (21)

To a solution of $2.2 \mathrm{ml}(15.7 \mathrm{mmol})$ of freshly distilled diisopropylamime and $6.0 \mathrm{ml}$ of dry THF, in a three necked round bottom flask, under a flux of $\mathrm{N}_{2}$, were added dropwise $9.8 \mathrm{ml}(15.7 \mathrm{mmol})$ of butyllithium $(1.6 \mathrm{M}$ in hexane). The mixture was kept under stirring at r.t. for 15 min. After that, the mixture was cooled at $-70{ }^{\circ} \mathrm{C}$ and 500 $\mathrm{mg}$ (3.1 mmol) of 20, dissolved in $10 \mathrm{ml}$ of dry THF, were added, and after $1 \mathrm{~h}$ a solution of iodine $(4.9 \mathrm{mmol})$ in 10 $\mathrm{ml}$ of dry THF was added dropwise.

After $1 \mathrm{~h}$ more at $-70{ }^{\circ} \mathrm{C} 4$ drops of glacial acetic acid and $3 \mathrm{ml}$ of methanol were added. The mixture was allowed to warm at r. t., the solvent was removed in vacuo and the residue was chromatographed on a silica gel column eluting with $\mathrm{CHCl}_{3}-\mathrm{CH}_{3} \mathrm{OH}$ (98:2) to give, after crystallization from $\mathrm{MeOH}, \mathbf{2 1}$, as white crystals. Yield $56 \%$, m.p. $247-249{ }^{\circ} \mathrm{C} ;{ }^{1} \mathrm{H}$ NMR (DMSO- $\left.d_{6}\right) \delta 1.31$ (t, $3 \mathrm{H}$, $J=7.2 \mathrm{~Hz}, \mathrm{CH}_{3}$ ); 4.12 (q, $2 \mathrm{H}, J=7.2 \mathrm{~Hz}, \mathrm{CH}_{2}$ ); 7.33 (br s, $\left.2 \mathrm{H}, \mathrm{NH}_{2}\right) ; 8.08(\mathrm{~s}, 1 \mathrm{H}, \mathrm{H}-2)$. Anal. Calcd. for $\mathrm{C}_{7} \mathrm{H}_{8} \mathrm{IN}_{5}$ (289.1): C, 29.08; H, 2.79; N, 24.23. Found: C, 29.44; H, 2.97; N, 24.02 .

\section{Biological evaluation}

Binding studies and adenylyl cyclase activity at human adenosine receptors

The radioligand binding experiments were carried out exactly as described previously [24]. For $\mathrm{A}_{1}$ adenosine receptor binding $1 \mathrm{nM}\left[{ }^{3} \mathrm{H}\right] \mathrm{CCPA}$ was used as a radioligand, whereas 30 and $10 \mathrm{nM}\left[{ }^{3} \mathrm{H}\right] \mathrm{NECA}$ was used for $\mathrm{A}_{2 \mathrm{~A}}$ and $\mathrm{A}_{3}$ receptors, respectively. Non specific binding was determined in the presence of $1 \mathrm{mM}$ theophylline $\left(\mathrm{A}_{1}\right)$ or $100 \mu \mathrm{M}$ R-PIA $\left(\mathrm{A}_{2 \mathrm{~A}}\right.$ and $\left.\mathrm{A}_{3}\right) . K_{\mathrm{i}}$ values were calculated from competition curves by nonlinear curve fitting with the program SCTFIT [25]. CHO cells stably transfected with human adenosine receptors were grown adherently and maintained in Dulbecco's Modified Eagles Medium with nutrient mixture F12 (DMEM/F12) without nucleosides, containing $10 \%$ fetal calf serum, penicillin $(100 \mathrm{U} / \mathrm{ml})$, streptomycin $(100 \mu \mathrm{g} / \mathrm{ml})$, L-glutamine $(2 \mathrm{mM})$ and Geneticin (G-418, $0.2 \mathrm{mg} / \mathrm{ml})$ at $37{ }^{\circ} \mathrm{C}$ in $5 \% \mathrm{CO}_{2} / 95 \%$ air as described earlier [24].

For radioligand binding studies and measurement of adenylyl cyclase activity crude membrane fractions were prepared from fresh or frozen cells with two different protocols which were described recently [24].

Determination of adenylyl cyclase activity followed the procedure described by [24]. $\mathrm{IC}_{50}$ values for the inhibition of cyclase stimulated with $5 \mu \mathrm{M}$ NECA were calculated with the Hill equation and converted to $K_{\mathrm{i}}$ values with the Cheng and Prusoff equation [24]. The Hill slopes were near unity suggesting a competitive interaction of the antagonists tested.

\section{Binding studies at rat adenosine receptors}

$\mathrm{A}_{1}$ and $\mathrm{A}_{2 \mathrm{~A}}$ receptor binding: Displacement of $\left[{ }^{3} \mathrm{H}\right] \mathrm{CHA}$ (31 $\mathrm{Ci} / \mathrm{mmol})$ from $A_{1}$ adenosine receptor in rat cortical membranes and of $\left[{ }^{3} \mathrm{H}\right] \mathrm{CGS} 21680(42.1 \mathrm{Ci} / \mathrm{mmol})$ from rat striatal membranes were performed as described [26]. 
$\left[{ }^{125} \mathrm{I}\right] \mathrm{AB}-\mathrm{MECA}$ binding to $\mathrm{A}_{3}$ receptor of rat testis membranes was performed in $50 \mathrm{mM}$ Tris, $10 \mathrm{mM} \mathrm{MgCl}$ and $1 \mathrm{mM}$ EDTA buffer (pH 7.4) containing $0.2 \mathrm{mg}$ of proteins and $25 \mathrm{nM} \mathrm{DPCPX}$, to selectively block $\mathrm{A}_{1}$ receptor subtypes. Incubations were carried out for $90 \mathrm{~min}$ at $25{ }^{\circ} \mathrm{C}$. Non-specific binding was determined in the presence of $50 \mu \mathrm{M}$ R-PIA and accounted to $30 \%$ of total binding. Binding reaction was terminated by rapid filtration through a Whatman $\mathrm{GF} / \mathrm{C}$ filter, washing three times with $5 \mathrm{ml}$ of ice-cold buffer.

All compounds were routinely dissolved in DMSO and diluted with assay buffer to the final concentration, where the amount of DMSO never exceeded 2\%. At least 6 different concentrations of each compound were used and $\mathrm{IC}_{50}$ values were computer-generated using nonlinear regression formula on a computer program (GraphPad, San Diego, CA). $\mathrm{IC}_{50}$ values were converted to $K_{\mathrm{i}}$ values, knowing the $K_{\mathrm{d}}$ values of radioligands in the different tissues and using the Cheng and Prusoff equation [27]. The dissociation constant $\left(K_{\mathrm{d}}\right)$ of $\left[{ }^{3} \mathrm{H}\right] \mathrm{CHA},\left[{ }^{3} \mathrm{H}\right] \mathrm{CGS}$ 21680 and $\left[{ }^{125} \mathrm{I}\right] \mathrm{AB}-\mathrm{MECA}$ were $1.2,10$ and $1.35 \mathrm{nM}$, respectively.

\section{Molecular modeling studies}

All the calculations were carried out utilizing the HyperChem 7.2 program (Hypercube, Gainesville, Florida, USA). For molecular mechanics calculations the AMBER 96 [28] force field was utilized with a distance-dependent dielectric constant scaled by a factor of 4 . All the energy minimizations were carried out employing the Polak-Ribiere conjugate gradient. All molecular dynamics simulations were carried at a constant temperature of 298 $\mathrm{K}$, using a timestep of $1 \mathrm{fs}$. Before the simulation, the system, virtually at $0 \mathrm{~K}$, was slowly ( $1 \mathrm{ps})$ heated until it reached the simulation temperature.

The human $\mathrm{A}_{3}$ model used for the docking experiments was the rhodopsin-based homology model previously constructed by us [17].

2-Phenylethynyl-9-ethyladenine (7) and 8-phenylethynyl-9-ethyladenine (17) were docked into the receptor helical bundle by modifying the ligands in $\mathrm{A}_{3} / 2$-phenylethynyladenosine or $\mathrm{A}_{3} / 8$-phenylethynyladenosine complex [17], respectively.

After applying a harmonic restraint of $7 \mathrm{kcal} / \mathrm{mol}$ to the backbone atoms of the protein, the receptor/ligand complexes were submitted to energy minimization (RMS $<0.5$ $\mathrm{kcal} / \mathrm{mol} / \AA \AA$ ), 10 ps of molecular dynamics, and energy minimization $(\mathrm{RMS}<0.001 \mathrm{kcal} / \mathrm{mol} / \AA$ ) .

\section{Results and discussion}

\section{Binding studies}

All the compounds were evaluated at the human recombinant adenosine receptors, stably transfected into Chinese hamster ovary $(\mathrm{CHO})$ cells, utilizing radioligand binding studies $\left(\mathrm{A}_{1}, \mathrm{~A}_{2 \mathrm{~A}}, \mathrm{~A}_{3}\right)$ or adenylyl cyclase activity assay
$\left(\mathrm{A}_{2 \mathrm{~B}}\right)$. Receptor binding affinity was determined using $\left[{ }^{3} \mathrm{H}\right] \mathrm{CCPA}$ (2-chloro- $\mathrm{N}^{6}$-cyclopentyladenosine) as the radioligand for $\mathrm{A}_{1}$ receptors, whereas $\left[{ }^{3} \mathrm{H}\right] \mathrm{NECA}\left(5^{\prime}-N\right.$ ethylcarboxamidoadenosine) was used for the $\mathrm{A}_{2 \mathrm{~A}}$ and $\mathrm{A}_{3}$ subtypes [24]. In the case of $\mathrm{A}_{2 \mathrm{~B}}$ receptors $K_{\mathrm{i}}$ values were calculated from $\mathrm{IC}_{50}$ values determined by inhibition of NECA-stimulated adenylyl cyclase activity.

The compounds were also tested for their affinity at rat cortex $A_{1}$, rat striatum $A_{2 A}$, and rat testis $A_{3}$ subtypes, using $\left[{ }^{3} \mathrm{H}\right] \mathrm{CHA}$ ( $\mathrm{N}^{6}$-cyclopentyladenosine), $\left[{ }^{3} \mathrm{H}\right] \mathrm{CGS}$ $21680\{2-p$-[(2-carboxyethyl)phenylethylamino $]-N$-ethylcarboxamidoadenosine $\}$, and $\left[{ }^{125} \mathrm{I}\right] \mathrm{ABMECA}\left[N^{6}-(4\right.$-amino-3-iodobenzyl)adenosine- $5^{\prime}-N$-methyluronamide] as the radioligands, respectively.

$K_{\mathrm{i}}$ values are in $\mu \mathrm{M}$ with $95 \%$ confidence intervals in parentheses. The results are shown in Table 1.

Biological data showed that the 2-alkynyl derivatives possess good affinity at all human adenosine receptors and are slightly selective for the $\mathrm{A}_{2 \mathrm{~A}}$ subtype.

Compounds 5 and $\mathbf{1 0}$ bearing a cyclohexylethyne and a phenylhydroxypropyne in 2-position, respectively, resulted in the most active of the series with $K_{\mathrm{i}}$ in the low nanomolar range both at human $\mathrm{A}_{1}$ and $\mathrm{A}_{2 \mathrm{~A}}$ receptors (5; $K_{\mathrm{i}} \mathrm{A}_{1}=0.080 \mu \mathrm{M}, K_{\mathrm{i}} \mathrm{A}_{2 \mathrm{~A}}=0.037 \mu \mathrm{M}$, and 10; $K_{\mathrm{i}} \mathrm{A}_{1}=$ $\left.0.098 \mu \mathrm{M}, K_{\mathrm{i}} \mathrm{A}_{2 \mathrm{~A}}=0.035 \mu \mathrm{M}\right)$.

At the $\mathrm{A}_{2 \mathrm{~B}}$ receptor the derivatives bearing linear chains in 2-position showed functional activity in the $\mu \mathrm{M}$ range $\left(2 ; K_{\mathrm{i}} \mathrm{A}_{2 \mathrm{~B}}=17 \mu \mathrm{M}, 3 ; K_{\mathrm{i}} \mathrm{A}_{2 \mathrm{~B}}=12 \mu \mathrm{M}\right.$, and $4 ; K_{\mathrm{i}} \mathrm{A}_{2 \mathrm{~B}}=19$ $\mu \mathrm{M})$, while the presence of sterically hindered substituents in the same position was detrimental for the activity. However, the presence of a phenylhydroxypropynyl chain seems to facilitate the interaction with the $A_{2 B}$ subtype, in fact the 2-phenylhydroxypropynyl-9-ethyladenine resulted the most active compound of the two series $\left(10 ; K_{\mathrm{i}} \mathrm{A}_{2 \mathrm{~B}}=\right.$ $1.4 \mu \mathrm{M})$. This finding is in agreement with our previous results obtained with the corresponding adenosine derivative. In fact, the $(R, S)$-2-phenyhydroxypropynyl- $N$ ethylcarboxamidoadenosine $\left[(R, S)\right.$-PHPNECA, $\mathrm{EC}_{50} \mathrm{~A}_{2 \mathrm{~B}}=$ $1.1 \mu \mathrm{M}]$ resulted in one of the most potent agonist with nucleoside structure at human $\mathrm{A}_{2 \mathrm{~B}}$ receptors reported so far [14, 29].

The affinity of the 2-alkynyl derivatives for the $\mathrm{A}_{3}$ subtype was lower than that at $\mathrm{A}_{1}$ and $\mathrm{A}_{2 \mathrm{~A}}$ receptors.

The same compounds, tested on the rat $A_{1}$ and $A_{2 A}$ subtypes, showed in general lower affinity for the rat $\mathrm{A}_{2 \mathrm{~A}}$ receptor, while compounds $\mathbf{7 - 9}$, bearing an aromatic ring in the 2-position, showed slightly higher affinity at the rat $A_{1}$ receptor, compared to the corresponding human receptor, hence resulting slightly $\mathrm{A}_{1}$ selective $\left(7 ; K_{\mathrm{i}} \mathrm{A}_{1}\right.$ (r) $=0.43 \mu \mathrm{M}$ vs $K_{\mathrm{i}} \mathrm{A}_{1}(\mathrm{~h})=0.77 \mu \mathrm{M}, 8 ; K_{\mathrm{i}} \mathrm{A}_{1}(\mathrm{r})=1.9 \mu \mathrm{M}$ vs $K_{\mathrm{i}} \mathrm{A}_{1}(\mathrm{~h})=8.3 \mu \mathrm{M}$, and 9; $K_{\mathrm{i}} \mathrm{A}_{1}(\mathrm{r})=0.15 \mu \mathrm{M}$ vs $K_{\mathrm{i}} \mathrm{A}_{1}$ (h) $=0.21 \mu \mathrm{M}$,). As in the case of human receptors, compounds 5 and $\mathbf{1 0}$ showed the highest affinity both at rat $\mathrm{A}_{1}$ and $\mathrm{A}_{2 \mathrm{~A}}$ subtypes $\left(5 ; K_{\mathrm{i}} \mathrm{A}_{1}=0.072 \mu \mathrm{M}, K_{\mathrm{i}} \mathrm{A}_{2 \mathrm{~A}}=\right.$ $0.069 \mu \mathrm{M}$, and 10; $\left.K_{\mathrm{i}} \mathrm{A}_{1}=0.14 \mu \mathrm{M}, K_{\mathrm{i}} \mathrm{A}_{2 \mathrm{~A}}=0.14 \mu \mathrm{M}\right)$.

At the rat $\mathrm{A}_{3}$ receptor these compounds showed comparable affinity to that at human one.

As far as the 8-alkynyl derivatives, their affinity at the human $\mathrm{A}_{1}, \mathrm{~A}_{2 \mathrm{~A}}$, and $\mathrm{A}_{2 \mathrm{~B}}$ receptors proved to be lower than 
Table 1. Affinities of 2- and 8-alkynyl-9-ethyladenines in radioligand binding assays at human and rat $\mathrm{A}_{1}, \mathrm{~A}_{2 \mathrm{~A}}$, and $\mathrm{A}_{3}$ adenosine receptors and effects on adenylate cyclase activity at human $\mathrm{A}_{2 \mathrm{~B}}$ adenosine receptor. ${ }^{\mathrm{a}}$
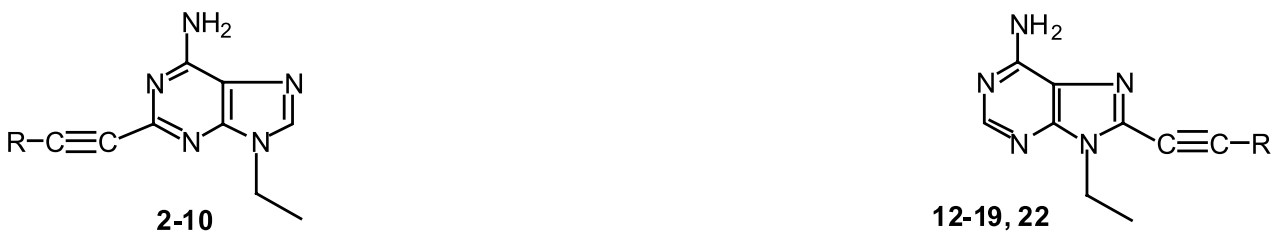

\begin{tabular}{|c|c|c|c|c|c|}
\hline \multirow[t]{2}{*}{ Cpd } & \multirow[t]{2}{*}{$R$} & \multicolumn{4}{|c|}{$K_{\mathrm{i}}, \mu \mathrm{M}$ or $\%$ inhibition } \\
\hline & & $K_{\mathrm{i}}\left(\mathrm{A}_{1}\right)^{\mathrm{b}}$ & $K_{\mathrm{i}}\left(A_{2 \mathrm{~A}}\right)^{\mathrm{c}}$ & $K_{\mathrm{i}}\left(\mathrm{A}_{2 \mathrm{~B}}\right)^{\mathrm{d}}$ & $K_{\mathrm{i}}\left(\mathrm{A}_{3}\right)^{\mathrm{e}}$ \\
\hline 2 & $-\left(\mathrm{CH}_{2}\right)_{2}-\mathrm{CH}_{3}$ & $\begin{array}{l}1.2(\mathrm{~h}) \\
(1.0-1.5) \\
4.6(\mathrm{r}) \\
(3.9-5.7)\end{array}$ & $\begin{array}{l}0.76(\mathrm{~h}) \\
(0.43-1.3) \\
2.9(\mathrm{r}) \\
(2.5-3.4)\end{array}$ & $\begin{array}{l}17(\mathrm{~h}) \\
(11-27)\end{array}$ & $\begin{array}{l}2.1(\mathrm{~h}) \\
(1.2-3.9) \\
8 \% \text { at } 10 \mu \mathrm{M}(\mathrm{r})\end{array}$ \\
\hline 3 & $-\left(\mathrm{CH}_{2}\right)_{3}-\mathrm{CH}_{3}$ & $\begin{array}{l}0.55(\mathrm{~h}) \\
(0.24-1.2) \\
0.98(\mathrm{r}) \\
(0.59-1.4)\end{array}$ & $\begin{array}{l}0.42(\mathrm{~h}) \\
(0.26-0.69) \\
0.72(\mathrm{r}) \\
(0.63-0.81)\end{array}$ & $\begin{array}{l}12(\mathrm{~h}) \\
(5.9-27)\end{array}$ & $\begin{array}{l}2.3(\mathrm{~h}) \\
(1.1-4.9) \\
1.3(\mathrm{r}) \\
(0.78-2.0)\end{array}$ \\
\hline 4 & $-\left(\mathrm{CH}_{2}\right)_{4}-\mathrm{OH}$ & $\begin{array}{l}3.6(\mathrm{~h}) \\
(2.9-4.6) \\
12(\mathrm{r}) \\
(10-14)\end{array}$ & $\begin{array}{l}1.9(\mathrm{~h}) \\
(1.1-3.3) \\
4.4(\mathrm{r}) \\
(3.5-5.4)\end{array}$ & $\begin{array}{l}19(\mathrm{~h}) \\
(10-35)\end{array}$ & $\begin{array}{l}14(\mathrm{~h}) \\
(6.5-32) \\
17 \% \text { at } 10 \mu \mathrm{M}(\mathrm{r})\end{array}$ \\
\hline 5 & -cyclohexyl & $\begin{array}{l}0.080(\mathrm{~h}) \\
(0.056-0.11) \\
0.072(\mathrm{r}) \\
(0.060-0.080)\end{array}$ & $\begin{array}{l}0.037(\mathrm{~h}) \\
(0.026-0.053) \\
0.069(\mathrm{r}) \\
(0.063-0.081)\end{array}$ & $\geq 30(\mathrm{~h})$ & $\begin{array}{l}3.6(\mathrm{~h}) \\
(2.8-4.8) \\
1.0(\mathrm{r}) \\
(0.46-2.2)\end{array}$ \\
\hline 6 & -cyclohexenyl & $\begin{array}{l}0.18(\mathrm{~h}) \\
(0.14-0.21) \\
0.17(\mathrm{r}) \\
(0.14-0.20)\end{array}$ & $\begin{array}{l}0.35(\mathrm{~h}) \\
(0.27-0.45) \\
0.80(\mathrm{r}) \\
(0.75-0.86)\end{array}$ & $>30(\mathrm{~h})$ & $\begin{array}{l}0.39(\mathrm{~h}) \\
(0.25-0.61) \\
3.5(\mathrm{r}) \\
(3.1-3.9)\end{array}$ \\
\hline 7 & $-\mathrm{C}_{6} \mathrm{H}_{5}$ & $\begin{array}{l}0.77(\mathrm{~h}) \\
(0.36-1.6) \\
0.43(\mathrm{r}) \\
(0.35-0.51)\end{array}$ & $\begin{array}{l}0.40(\mathrm{~h}) \\
(0.24-0.67) \\
0.81(\mathrm{r}) \\
(0.67-0.96)\end{array}$ & $>30(\mathrm{~h})$ & $\begin{array}{l}0.52(\mathrm{~h}) \\
(0.35-0.78) \\
3.0(\mathrm{r}) \\
(0.97-6.2)\end{array}$ \\
\hline 8 & $-\mathrm{C}_{6} \mathrm{H}_{4}-p-\mathrm{COCH}_{3}$ & $\begin{array}{l}8.3(\mathrm{~h}) \\
(5.1-14) \\
1.9(\mathrm{r}) \\
(1.5-2.4)\end{array}$ & $\begin{array}{l}3.8(\mathrm{~h}) \\
(1.9-7.7) \\
5.8(\mathrm{r}) \\
(4.6-7.1)\end{array}$ & $>30(\mathrm{~h})$ & $\begin{array}{l}>100(\mathrm{~h}) \\
11 \% \text { at } 10 \mu \mathrm{M}(\mathrm{r})\end{array}$ \\
\hline 9 & $-\left(\mathrm{CH}_{2}\right)_{2}-\mathrm{C}_{6} \mathrm{H}_{5}$ & $\begin{array}{l}0.21(\mathrm{~h}) \\
(0.12-0.39) \\
0.15(\mathrm{r}) \\
(0.09-0.24)\end{array}$ & $\begin{array}{l}0.15(\mathrm{~h}) \\
(0.091-0.23) \\
2.7(\mathrm{r}) \\
(2.0-3.4)\end{array}$ & $>30.0(\mathrm{~h})$ & $\begin{array}{l}4.1(\mathrm{~h}) \\
(2.9-5.6) \\
4.8(\mathrm{r}) \\
(4.4-5.3)\end{array}$ \\
\hline 10 & $(R, S)-\mathrm{CH}(\mathrm{OH}) \mathrm{C}_{6} \mathrm{H}_{5}$ & $\begin{array}{l}0.098(\mathrm{~h}) \\
(0.092-0.10) \\
0.14(\mathrm{r}) \\
(0.11-0.17)\end{array}$ & $\begin{array}{l}0.035(\mathrm{~h}) \\
(0.018-0.072) \\
0.14(\mathrm{r}) \\
(0.10-0.21)\end{array}$ & $\begin{array}{l}1.4(\mathrm{~h}) \\
(0.85-2.3)\end{array}$ & $\begin{array}{l}4.3(\mathrm{~h}) \\
(3.0-6.2) \\
1.2(\mathrm{r}) \\
(0.58-2.0)\end{array}$ \\
\hline 12 & $-\left(\mathrm{CH}_{2}\right)_{2}-\mathrm{CH}_{3}$ & $\begin{array}{l}0.064(\mathrm{~h}) \\
(0.025-0.17) \\
0.24(\mathrm{r}) \\
(0.17-0.32)\end{array}$ & $\begin{array}{l}0.37(\mathrm{~h}) \\
(0.27-0.50) \\
1.4(\mathrm{r}) \\
(1.1-1.8)\end{array}$ & $\begin{array}{l}2.7(\mathrm{~h}) \\
(2.5-2.9)\end{array}$ & $\begin{array}{l}0.59(\mathrm{~h}) \\
(0.22-1.6) \\
1.5(\mathrm{r}) \\
(1.1-1.9)\end{array}$ \\
\hline 13 & $-\left(\mathrm{CH}_{2}\right)_{3}-\mathrm{CH}_{3}$ & $\begin{array}{l}2.3(\mathrm{~h}) \\
(1.4-3.9) \\
4.6(\mathrm{r}) \\
(3.6-5.7)\end{array}$ & $\begin{array}{l}0.44(\mathrm{~h}) \\
(0.22-0.87) \\
0.82(\mathrm{r}) \\
(0.72-0.94)\end{array}$ & $\begin{array}{l}22(h) \\
(11-45)\end{array}$ & $\begin{array}{l}0.62(\mathrm{~h}) \\
(0.34-1.1) \\
3.5(\mathrm{r}) \\
(2.8-4.2)\end{array}$ \\
\hline 14 & $-\left(\mathrm{CH}_{2}\right)_{4}-\mathrm{OH}$ & $\begin{array}{l}6.5(\mathrm{~h}) \\
(5.5-7.5) \\
12 \% \text { a } 10 \mu \mathrm{M}(\mathrm{r})\end{array}$ & $\begin{array}{l}1.6(\mathrm{~h}) \\
(0.84-3.0) \\
13(\mathrm{r}) \\
(8.8-18)\end{array}$ & $\begin{array}{l}21(\mathrm{~h}) \\
(19-24)\end{array}$ & $\begin{array}{l}6.6(\mathrm{~h}) \\
(3.5-12) \\
23(\mathrm{r}) \\
(18-29)\end{array}$ \\
\hline 15 & -cyclohexyl & $\begin{array}{l}0.60(\mathrm{~h}) \\
(0.48-0.69) \\
\text { nd }(\mathrm{r})\end{array}$ & $\begin{array}{l}0.36(\mathrm{~h}) \\
(0.11-0.43) \\
\text { nd }(\mathrm{r})\end{array}$ & $>100(\mathrm{~h})$ & $\begin{array}{l}2.2(\mathrm{~h}) \\
(1.5-2.7) \\
\text { nd }(\mathrm{r})\end{array}$ \\
\hline 16 & -cyclohexenyl & $\begin{array}{l}1.2(\mathrm{~h}) \\
(0.66-2.1) \\
1.0(\mathrm{r}) \\
(0.68-1.4)\end{array}$ & $\begin{array}{l}2.0(\mathrm{~h}) \\
(1.2-3.4) \\
3.8(\mathrm{r}) \\
(3.1-4.5)\end{array}$ & $>100(\mathrm{~h})$ & $\begin{array}{l}0.43(\mathrm{~h}) \\
(0.23-0.80) \\
2.2(\mathrm{r}) \\
(1.9-4.0)\end{array}$ \\
\hline
\end{tabular}


Table 1. Continued.

\begin{tabular}{|c|c|c|c|c|c|}
\hline \multirow[t]{2}{*}{ Cpd } & \multirow[t]{2}{*}{$R$} & \multicolumn{2}{|c|}{$K_{\mathrm{i}}, \mu \mathrm{M}$ or $\%$ inhibition } & \multirow[b]{2}{*}{$K_{\mathrm{i}}\left(\mathrm{A}_{2 \mathrm{~B}}\right)^{\mathrm{d}}$} & \multirow[b]{2}{*}{$K_{\mathrm{i}}\left(\mathrm{A}_{3}\right)^{\mathrm{e}}$} \\
\hline & & $K_{\mathrm{i}}\left(\mathrm{A}_{1}\right)^{\mathrm{b}}$ & $K_{\mathrm{i}}\left(A_{2 \mathrm{~A}}\right)^{\mathrm{c}}$ & & \\
\hline 17 & $-\mathrm{C}_{6} \mathrm{H}_{5}$ & $\begin{array}{l}1.3(\mathrm{~h}) \\
(0.94-1.7) \\
2.6(\mathrm{r}) \\
(2.0-3.3)\end{array}$ & $\begin{array}{l}0.60(\mathrm{~h}) \\
(0.64-1.1) \\
0.64(\mathrm{r}) \\
(0.48-0.82)\end{array}$ & $\geq 30(\mathrm{~h})$ & $\begin{array}{l}0.086(\mathrm{~h}) \\
(0.067-0.11) \\
0.25(\mathrm{r}) \\
(0.12-0.43)\end{array}$ \\
\hline 18 & $-\mathrm{C}_{6} \mathrm{H}_{4}-p-\mathrm{COCH}_{3}$ & $\begin{array}{l}>100(\mathrm{~h}) \\
10 \% \text { a } 10 \mu \mathrm{M}(\mathrm{r})\end{array}$ & $\begin{array}{l}25 \\
(13-47) \\
5.4(\mathrm{r}) \\
(4.0-7.0)\end{array}$ & $>30(\mathrm{~h})$ & $\begin{array}{l}>100(\mathrm{~h}) \\
5 \% \text { a } 10 \mu \mathrm{M}(\mathrm{r})\end{array}$ \\
\hline 19 & $-\left(\mathrm{CH}_{2}\right)_{2}-\mathrm{C}_{6} \mathrm{H}_{5}$ & $\begin{array}{l}4.6(\mathrm{~h}) \\
(2.6-8.1) \\
2.5(\mathrm{r}) \\
(1.4-4.0)\end{array}$ & $\begin{array}{l}1.6(\mathrm{~h}) \\
(0.75-3.5) \\
2.7(\mathrm{r}) \\
(1.0-2.5)\end{array}$ & $>100(\mathrm{~h})$ & $\begin{array}{l}3.2(\mathrm{~h}) \\
(2.2-4.7) \\
5.3(\mathrm{r}) \\
(3.4-7.6)\end{array}$ \\
\hline 22 & $(R, S)-\mathrm{CH}(\mathrm{OH}) \mathrm{C}_{6} \mathrm{H}_{5}$ & $\begin{array}{l}3.0(\mathrm{~h}) \\
(1.6-5.6) \\
4.0(\mathrm{r}) \\
(2.3-6.1)\end{array}$ & $\begin{array}{l}0.88(\mathrm{~h}) \\
(0.55-1.4) \\
0.94(\mathrm{r}) \\
(0.68-1.2)\end{array}$ & $\geq 30.0(\mathrm{~h})$ & $\begin{array}{l}3.7(\mathrm{~h}) \\
(2.9-4.6) \\
2.1(\mathrm{r}) \\
(1.3-3.0)\end{array}$ \\
\hline
\end{tabular}

\footnotetext{
${ }^{a}$ Species are given in brackets: $\mathrm{h}=$ human, $\mathrm{r}=$ rat. $K_{\mathrm{i}}$ values are in $\mu \mathrm{M}$ with $95 \%$ confidence intervals in parentheses.

${ }^{b}$ Displacement of specific $\left[{ }^{3} \mathrm{H}\right] \mathrm{CCPA}$ binding in $\mathrm{CHO}$ cells, stably transfected with human recombinant $\mathrm{A}_{1}$ adenosine receptor, and displacement of specific $\left[{ }^{3} \mathrm{H}\right] \mathrm{CHA}$ binding in rat cortical membranes or percentage of inhibition of specific binding at $10 \mu \mathrm{M}$ concentration.

${ }^{\mathrm{c}}$ Displacement of specific $\left[{ }^{3} \mathrm{H}\right] \mathrm{NECA}$ binding in $\mathrm{CHO}$ cells, stably transfected with human recombinant $\mathrm{A}_{2 \mathrm{~A}}$ adenosine receptor, and displacement of specific $\left[{ }^{3} \mathrm{H}\right] \mathrm{CGS} 21680$ binding in rat striatal membranes.

${ }^{\mathrm{d}}$ Measurement of receptor-stimulated adenylyl cyclase activity in $\mathrm{CHO}$ cells, stably transfected with human recombinant $\mathrm{A}_{2 \mathrm{~B}}$ adenosine receptor. $K_{\mathrm{i}}$ values were calculated from $\mathrm{IC}_{50}$ values determined by inhibition of NECA-stimulated adenylyl cyclase activity.

${ }^{\mathrm{e}}$ Displacement of specific $\left[{ }^{3} \mathrm{H}\right] \mathrm{NECA}$ binding in $\mathrm{CHO}$ cells, stably transfected with human recombinant $\mathrm{A}_{3}$ adenosine receptor, and displacement of specific $\left[{ }^{125} \mathrm{I}\right] \mathrm{AB}-\mathrm{MECA}$ binding in rat testis membranes or percentage of inhibition of specific binding at $10 \mu \mathrm{M}$ concentration.
}

that of the corresponding 2-alkynyl analogues, with the exception of compound $12\left(12 ; K_{\mathrm{i}} \mathrm{A}_{1}=0.064 \mu \mathrm{M}, K_{\mathrm{i}} \mathrm{A}_{2 \mathrm{~A}}=\right.$ $0.37 \mu \mathrm{M}, K_{\mathrm{i}} \mathrm{A}_{2 \mathrm{~B}}=2.7 \mu \mathrm{M}$, and $K_{\mathrm{i}} \mathrm{A}_{3}=0.59 \mu \mathrm{M}$ vs $2 ; K_{\mathrm{i}}$ $\mathrm{A}_{1}=1.2 \mu \mathrm{M}, K_{\mathrm{i}} \mathrm{A}_{2 \mathrm{~A}}=0.76 \mu \mathrm{M}, K_{\mathrm{i}} \mathrm{A}_{2 \mathrm{~B}}=17 \mu \mathrm{M}$, and $K_{\mathrm{i}}$ $\left.\mathrm{A}_{3}=2.1 \mu \mathrm{M}\right)$.

However, it is worthwhile to note that the derivatives, which showed some activity at the $\mathrm{A}_{2 \mathrm{~B}}$ receptor, are those bearing linear chains in the 8-position, as in the case of the 2-substituted compounds $\left(12 ; K_{\mathrm{i}} \mathrm{A}_{2 \mathrm{~B}}=2.7 \mu \mathrm{M}, 13 ; K_{\mathrm{i}}\right.$ $\mathrm{A}_{2 \mathrm{~B}}=22 \mu \mathrm{M}$, and 14; $\left.K_{\mathrm{i}} \mathrm{A}_{2 \mathrm{~B}}=21 \mu \mathrm{M}\right)$.

On the contrary, the affinity of the 8-alkynyl derivatives for the human $\mathrm{A}_{3}$ receptor, compared to the corresponding 2-substituted derivatives, was improved; hence the 8phenylethynyl-9-ethyladenine (17) with a $K_{\mathrm{i}} \mathrm{A}_{3}$ (h) of 0.086 and $0.25 \mu \mathrm{M}(\mathrm{r})$ resulted the most active compound of the two series at both the human and rat $\mathrm{A}_{3}$ subtype and was $\mathrm{A}_{3}$ selective.

As in the case of the 2-substituted compound, the 8alkynyl derivatives showed decreased affinity for rat receptors. The selectivity of this series of derivatives for the $A_{1}, A_{2 A}$, and $A_{3}$ receptor subtypes was strictly correlated to the nature of the alkynyl chain, and there is a good correlation between affinity at human and rat receptors.

\section{Molecular modeling}

In order to get an insight into the mechanism of the ligand recognition and to give a rational explanation of the preference of the human $\mathrm{A}_{3}$ receptor for the 8-substituted compounds rather than the 2-substituted compounds in this series, we carried out docking experiments of 2-phenylethynyl-9-ethyladenine (7) and 8-phenylethynyl-9-ethyladenine (17) at a rhodopsin-based homology model of the receptor (Figure 1).

In a previous molecular modeling study [17], we proposed that 2- and 8-alkynyl derivatives of adenosine bind to the human $A_{3}$ receptor in a way that the $C 2$ of a molecule matches the $\mathrm{C} 8$ of the other one, with a good steric and electrostatic overlap of the purine moieties and the alkynyl chains.

On the basis of the structure activity relationships data, we hypothesized a similar binding mode for the alkynyl derivatives of adenosine and the correspondent 9-ethyladenine analogues. The results of our docking experiments were in good agreement with the biological data, confirming the soundness of the hypothesis on which they were based.

In the case of the adenosine derivatives, the compounds substituted at the 2-position were endowed with higher affinity than the correspondent 8-substituted analogues. In fact, in the latter case the sugar moiety had unfavourable interactions with the receptor.

On the other hand, in the case of the 2- and 8phenylethynyl-9-ethyladenine, due to the substitution of the ribose moiety with the less bulky ethyl group, the negative ligand receptor interactions were eliminated even in the case of the 8-substituted compound. According to the results of the present study, in both situations the ethyl group is accommodated in the hydrophobic 


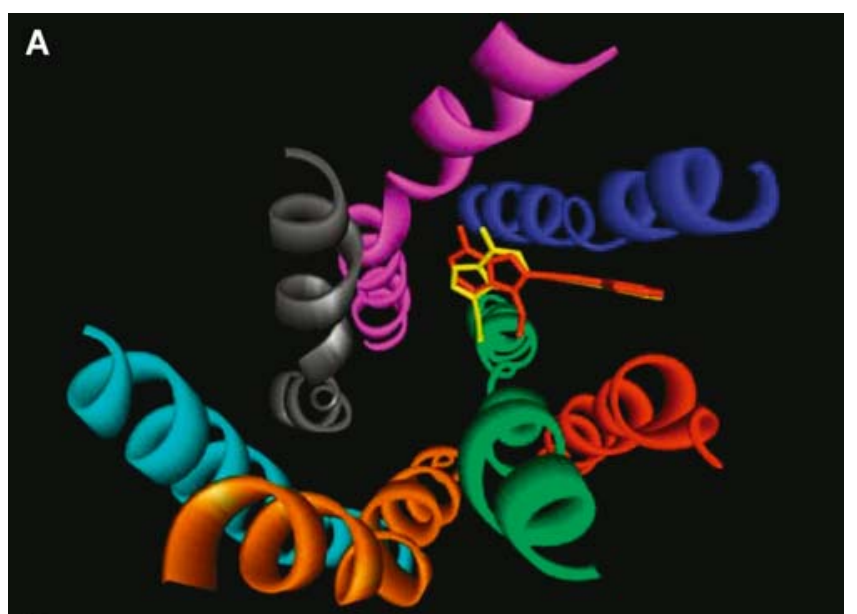

Conclusions

With this study we have demonstrated that it is possible to modulate the activity at the adenosine receptor subtypes by introducing alkynyl chains in the 2- or 8-position of the 9ethyladenine.

Although all the synthesized compounds were more active at human receptors, it is worthwhile to note that, in the series of the 2-substituted derivatives, compounds 5 and $\mathbf{1 0}$ are the ones endowed with the highest affinity at both human and rat $\mathrm{A}_{1}$ and $\mathrm{A}_{2 \mathrm{~A}}$ receptors.

The same trend has been observed with the 8-substituted derivatives: in fact the 8-phenylethynyl-9-ethyladenine (17) proved to be the most active and selective compound of the two series at human and rat $\mathrm{A}_{3}$ subtype.

From these results it is possible to conclude that the

B N250 (TM6)

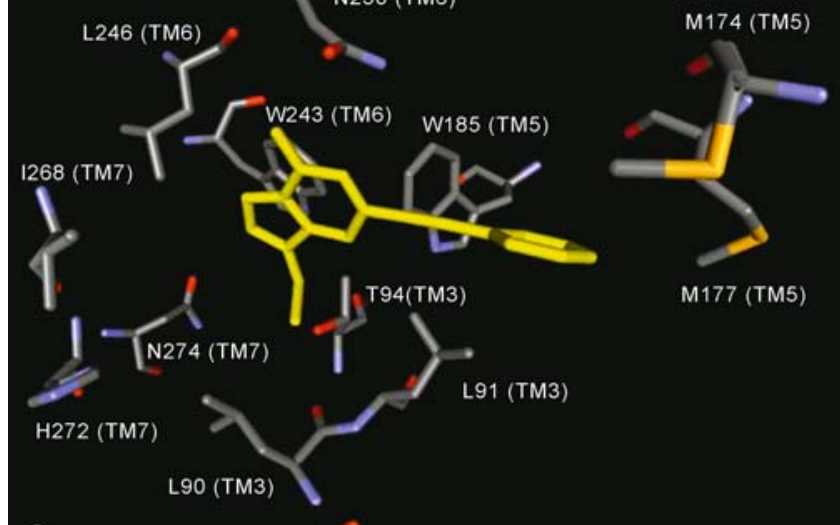

C

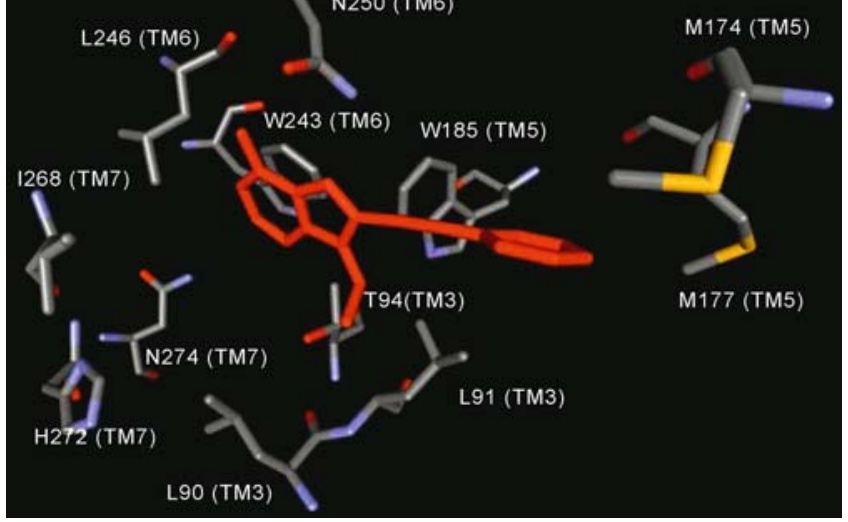

Figure 1. 2-Phenylethynyl-9-ethyladenine (7, yellow) and 8-phenylethynyl-9-ethyladenine $(\mathbf{1 7}$, red) docked into the seven transmembrane domain of the human $\mathrm{A}_{3}$ receptor. (A) View from outside the cell. (B and C) Detailed view of the two antagonists within the human $A_{3}$ receptor binding pocket. Color of helices: Cyan (TM1), orange (TM2), green (TM3), red (TM4), blue (TM5) magenta (TM6), gray (TM7).

pocket formed by Leu 90 and Leu 91 of the third transmembrane domain (TM3). Furthermore, the binding of the 8-alkynyl derivative to the $\mathrm{A}_{3}$ receptor appears to be facilitated by a stronger electrostatic interaction of the crucial Asn 250 (TM6) with the adenine ring compared to the case of the 2-alkynyl derivatives (Figure 1). selectivity of these two series of derivatives for the $A_{1}$, $A_{2 A}$, and $A_{3}$ receptor subtypes is strictly correlated to the nature of the alkynyl chain, and that there is a good correlation between the affinity at human and rat receptors.

\section{Acknowledgements}

Supported by a grant from the Ministry of Research (COFIN, Grant no. 200061553, 2002) and by the University of Camerino (Fondo di Ricerca di Ateneo).

\section{References}

1. Poulsen SA, Quinn RJ. Adenosine receptors: New opportunity for future drugs. Bioorg Med Chem 1998; 6: 619-41.

2. Robeva AS, Woodard RL, Ji XD et al. Drug Dev Res 1996; 39 : 243-52.

3. Fredholm BB, IJzerman AP, Klotz K-N, Linden J. International Union of Pharmacology. XXV. Nomenclature and classification of adenosine receptors. Pharmacol Rev 2001; 53: 527-33.

4. Fredholm BB, Arslan G, Halldner L et al. Structure and function of adenosine receptors and their genes. Naunyn Schmiedeberg's Arch Pharmacol 2000; 362: 364-74.

5. Müller CE. $\mathrm{A}_{3}$ Adenosine receptor antagonists. Mini Rev Med Chem 2001; 1: 433-43.

6. Müller CE. Medicinal chemistry of adenosine $\mathrm{A}_{3}$ receptor ligands. Curr Topics Med Chem 2003; 3: 345-462.

7. Adenosine receptors: Medicinal chemistry, pharmacology and therapeutic applications. In Cristalli G, Volpini R (eds): Curr Topics Med Chem 2003; 3: 355-469.

8. Hess S. Recent advances in adenosine receptor antagonist research. Expert Opin Ther Patents 2001; 11: 1-29.

9. Müller CE, Stein B. Adenosine receptor antagonists: Structure and potential therapeutic applications. Curr Pharm Des 1996; 2: 501-30.

10. Cristalli G, Eleuteri A, Vittori $\mathrm{S}$ et al. 2-Alkynyl derivatives of adenosine and adenosine-5'- $N$-ethyluronamide as selective agonists at $\mathrm{A}_{2}$ adenosine receptors. J Med Chem 1992; 35: 2363-8.

11. Cristalli G, Volpini R, Vittori $\mathrm{S}$ et al. 2-Alkynyl derivatives of adenosine- $5^{\prime}$ - $N$-ethyluronamide (NECA) as selective agonists at $\mathrm{A}_{2}$ adenosine receptor agonists with potent inhibitory activity on platelet aggregation. J Med Chem 1994; 37: 1720-6.

12. Cristalli G, Camaioni E, Vittori S et al. 2-Aralkynyl and 2heteroalkynyl derivatives of adenosine- 5 ' $-N$-ethyluronamide as selective $\mathrm{A}_{2 \mathrm{a}}$ adenosine receptor agonists. J Med Chem 1995; 38: 1462-72.

13. Camaioni E, Di Francesco E, Vittori S et al. Adenosine receptor 
agonists: Synthesis and biological evaluation of the diastereoisomers of 2-(3-hydroxy-3-phenyl-1-propyn-1yl)NECA. Bioorg Med Chem 1997; 5: 2267-75.

14. Volpini R, Costanzi S, Lambertucci C et al. $N^{6}$-Alkyl-2-alkynyl derivatives of adenosine as potent and selective agonists at the human adenosine $A_{3}$ receptor and a starting point for searching $A_{2 B}$ ligands. J Med Chem 2002; 45: 3271-9.

15. Volpini R, Costanzi S, Lambertucci $\mathrm{C}$ et al. Purine nucleosides bearing 1-alkynyl chains as adenosine receptor agonists. Curr Pharm Design 2002; 8: 99-110.

16. Volpini R, Costanzi S, Lambertucci $\mathrm{C}$ et al. Introduction of alkynyl chains on $\mathrm{C}-8$ of adenosine led to very selective antagonists of the $\mathrm{A}_{3}$ adenosine receptor. Bioorg Med Chem. Lett 2001; 11: 1931-4.

17. Costanzi S, Lambertucci C, Vittori S et al. 2- And 8-alkynyladenosines: Conformational studies and docking to human adenosine $\mathrm{A}_{3}$ receptor can explain their different biological behavior. J Mol Graph Model 2003; 21: 253-62.

18. Camaioni E, Costanzi S, Vittori S et al. New substituted 9alkylpurines as adenosine receptor ligands. Bioor Med Chem 1998; 6: 523-33.

19. Cristalli G, Camaioni E, Costanzi S et al. Characterization of potent ligands at human recombinant adenosine receptors. Drug Dev Res 1998; 45: 176-81.

20. Klotz KN, Kachler S, Lambertucci C et al. 9-Ethyladenine derivatives as adendosine receptor antagonists: 2- and 8-substitution results in distinct selectivities. Naunyn-Schmiedeberg's Arch Pharmacol 2003; 367: 629-34.

21. May JM, Martin PL, Miller JR. N-0861: A selective $A_{1}$-adenosine receptor antagonist. Fed Am Soc Exp Biol J 1991; 5: 572.

22. Harada H, Asano O, Hoshino $\mathrm{Y}$ et al. 2-Alkynyl-8-aryl-9-methyl- adenines as novel adenosine receptor antagonists: their synthesis and structure-activity relationships toward hepatic glucose production induced via agonism of the $\mathrm{A}_{2 \mathrm{~B}}$ receptor. J Med Chem 2001; 44: $170-9$.

23. de Ligt RAF, van der Klein PAM, von Frijtag Drabbe Künzel JK et al. Synthesis and biological evaluation of disubstituted $N^{6}$ cyclopentyladenine analogues: The search for a neutral antagonists with high affinity for the adenosine $\mathrm{A}_{1}$ receptor. Bioorg Med Chem 2004; 12: 139-49.

24. Klotz KN, Hessling J, Hegler J et al. Comparative pharmacology of human adenosine subtypes-characterization of stably transfected receptors in CHO cells. Naunyn-Schmiedeberg's Arch Pharmacol 1998; 357: 1-9.

25. De Lean A, Hancock AA, Lefkowitz RJ. Validation and statistical analysis of a computer modeling method for quantitative analysis of radioligand binding data for mixtures of pharmacological receptor subtypes. Mol Pharmacol 1982; 21: 5-16.

26. Colotta V, Catarzi D, Varano F et al. 1,2,4-Triazolo[4,3-a]quinoxalin-1-one: A versatile tool for the synthesis of potent and selective adenosine receptor antagonists. J Med Chem 2000; 43: 1158-64.

27. Cheng YC, Prusoff WH. Relation between the inhibition constant $K_{\mathrm{i}}$ and the concentration of inhibitor which causes fifty percent inhibition $\left(\mathrm{IC}_{50}\right)$ of an enzyme reaction. Biochem Pharmacol 1973; 22: 3099-108.

28. Cornell WD, Cieplak P, Bayly CI et al. A second generation force field for the simulation of proteins, nucleic acids, and organic molecules. J Am Chem Soc. 1995; 117: 5179-97.

29. Volpini R, Costanzi S, Vittori S et al. Medicinal chemistry and pharmacology of $\mathrm{A}_{2 \mathrm{~B}}$ adenosine receptors. Curr Topics Med Chem 2003; 3: 427-43. 